\title{
Analysis of the potential contribution of forestry sub- sector in economic and development in daerah istimewa yogyakarta province
}

\author{
Faid Nurul Elmi ${ }^{1 *}$, Bambang Azis Nur ${ }^{2}$, and Maryono Maryono ${ }^{3}$ \\ ${ }^{1}$ Master Program in Environmental Science, Diponegoro University, Semarang - Indonesia \\ ${ }^{2}$ Faculty of Marine and Fisheries, Diponegoro University, Semarang - Indonesia \\ ${ }^{3}$ Department of Urban and Regional Planning, Diponegoro University, Semarang - Indonesia
}

\begin{abstract}
The forestry sub-sector is one of the subsectors of the agricultural sector that has an opportunity to support the economic development program, contribute to the Gross Regional Domestic Product (GRDP) and reduce unemployment rate in Daerah Istimewa Yogyakarta (hereafter, DIY Province). The economic growth of DIY Province in 2012-2016 for the forestry sub-sector tends to increase. The objective of this research is to identify and analyze the opportunities of the forestry sub-sector to be used as a reference and as a regional leading sector for improving the economy in DIY Province. This research uses a descriptive analytical method. Location Quotient (LQ) method, modification LQ (Revised LQ and Symmetric LQ) are tools of analysis. The data used is some data from GRDP in the year 2012-2016 based on the fixed price in the year 2010. Based on the calculation of LQ, SLQ and RLQ analysis where obtained LQ value equal to 1.23 , RLQ of 1.23 and SLQ of 0.10 indicates that the forestry sub-sector can still be expected to be the regional leading sector in the future to increase economic growth in DIY Province. The forestry sub-sector has potential to become the leading sector in Gunungkidul Regency and Kulonprogo Regency.
\end{abstract}

Keywords: forestry sub-sector; regional leading sector; LQ; Revised LQ; Symmetric LQ

Forestry sub-sector plays an important role in

\section{INTRODUCTION}

In line with the Ministry of National Development Planning/Bappenas Plans which is currently drafting a Presidential Regulation on Low Carbon Development Planning (PPRK) in order to help reduce carbon emissions by $26 \%$ in 2020 , the determination of policies requires simulations using dynamic models that include the sectors of agriculture, forestry, mining, and others. According to Bappenas data, the potential for achieving greenhouse gas emission reduction until 2016 only reached $10.6 \%$ and expected to increase to $13.47 \%$, if includes the forestry subsector. [1]

Therefore, In this era of reformation as national development has been implemented, Indonesia shows the fact that agricultural sector (including forestry subsector) still becomes the largest livelihood for Indonesian people or constitutes the most dominant sector (leading sector) in national economy, and it has been proven that it becomes the most resistant sector to the economic and monetary crisis. [2]. The leading sector is defined as a sector that is able to trigger and to support development of other sectors. [3] national economy through foreign exchange, the provisions of place and raw material for industry, area expansion, creation of job vacancy, the increase of people's income, and area development. The real contribution of the forestry sector can be seen through the state income of the forestry sector for about 7-8 billion dollars each year, tax and non-tax revenues, direct labor absorption for 4 million people (with multiplier effect is 10-20 million people), the development of region's economic growth through 46 thousand kilometers of road across Indonesia as well as other public facilities like schools, places of worship, etc. [4]

The economic development of the forestry sector is also supported by Indonesia, which is a tropical country with high potential of forest resources spreading throughout its land in each region. Being the world's third largest tropical forest, Indonesia's forest have significant role in the climate change mitigation at the national and global levels. Besides ecological, cultural, and spiritual value, forest also plays important role in perceiving national economy and supporting livelihood through ecosystem service and job opportunity. [5] 
In the New Order era, forestry sub-sector plays a big role in increasing foreign exchange (the second important sector after petroleum) supported by the political economy leading to "wood boom" in the beginning of 1980s. [6]. Forestry has big role in economy. However, looking at the Gross Regional Domestic Product (GRDP) in several regions, it is shown that the roles and contribution of forestry sector is still very small. [6] The small contribution from the forestry sector to GRDP is due to the calculation that is solely based on primary commodities, namely wood, rattan, forestry service, etc. [7]

Since 2005, forestry sub-sector in Indonesia has contributed only $1 \%$ to Gross Domestic Product (GDP); even, it goes down in 2009 , only $0.8 \%$. The average contribution of forestry sub-sector to GDP is less than $1.3 \%$. The contribution of forestry sector to GDP is small, that is, only about $1 \%$, and if the processed wood products are also included, the increase is up to $2 \%$ only. However, other sectors like plantation, livestock and its products, as well as fishery also have approximately the same contribution, that is, $2 \%$. [8]

Since the exploitation of natural forests outside Java has been opened, there are impacts on the extent of cover and potential of forest per hectare that continues to decline. GDP of forestry sector and its products experience negative growth. In 2004-209, GDP of forestry sub-sector had negative growth about $0.40 \%$ per year, and the wood industry sector and other products have also negative growth as much as $0.57 \%$ per year. The negative growth of GDP of forestry sub-sector and its products indicates that the utilization of forest is not carried out sustainably. [8]

Moreover, thinking about the role of forestry sector in the development in that way may give bad impact for the condition of the forests being damaged and "chaos", and the position of the forestry sector becomes marginalized (considered unimportant compared to economic resources in other sectors). [6]

In terms of the forestry sector, the main problem is not on how much contribution that has been given to GDP, but how big is the multiplier effect for economy and is there any forest resource that can be utilized sustainably? Without the increase of wood production, contribution from the forestry sub-sector may reach more than $2 \%$ if there are no illegal logging, inefficiency of the forest utilization, wood process, as well as the undistorted domestic log, especially the policy of log export ban. However, as for the example, Malaysia and United States do not apply the ban policy, but they allow log export even though the logs of forests in United States are for domestic market. [8]

Development pattern of forestry sub-sector is also influenced by regional development that becomes the foundation of national development. It is due to the fact that in the era of regional autonomy, each region is required to optimize the potential of natural resources of which purpose is to dig the sources of local revenue in order to increase regional development.[9]. Therefore, a region should be able to determine which sectors are superior, either for the present or future, so that the regional development can be directed to the development of the leading sectors resulting in other sectors' development. [3].

As it has been reported in some researches stating that agriculture, forestry, and fisheries sectors still become the basic/leading sectors in the DIY Province. Thus, it can be said that the forestry sub-sector also becomes leading sector.

However, the contribution of forestry sub-sector tends to decrease, but it does not affect agriculture, forestry, and fishery sectors towards the economic growth in the DIY Province as it still becomes leading sector in the DIY Province with the average contribution from 2012 to 2016, which is still the largest contribution to GRDP distribution in economic sector, is $23.73 \%$. Meanwhile, forestry and logging sub-sector of the DIY Province from 2012 to 2016 have given the average contribution of $3.50 \%$ at the constant prices in 2010 . The decrease in the contribution of forestry sub-sector from 2012 to 2016 is due to the fact that economic sectors in DIY Province in the same year also have the increased value of GRDP. It shows the tendency of transformation/shifting role of economic sectors in DIY Province.

Based on the information above, there should be an analysis whether forestry sub-sector is included in excellent sector and potential to develop as supporting item for economic development, and it is also expected that the analysis be used to arrange strategy for regional development through optimal forest management in DIY Province based on LQ, RLQ, and SLQ method with GRDP approach at constant price of 2010 .

\section{METHODOLOGY}

This research is conducted in DIY Province covering 5 (five) regencies, namely Sleman, Bantul, Kulon Progo, and Gunung Kidul, and 1(one) city, that is, Yogyakarta.This research uses quantitative data, which is in the form of numbers, and the values are changeable or various.

Type of this research is descriptive analysis with quantitative approach to explain and to summarize several conditions, situations, and variables occurring in public being the object of the research based on the real data. [10]

This study uses secondary data obtained from library and literary review as well as journals that include concept, theory, model, and framework of journals, paper or research report, and books discussing about problem statement. The data is collected based on time series in the form of annual data of 2012-2016 (5 years) from Central Bureau of Statistics of DIY Province (20122016), annual data of 2012-2016 (5 years) from Central Bureau of Statistics of each regency od DIY Province [11], [12], [13], [14], [15] and also data of GRDP at constant price of 2010 according to Business Field and 
Gross Domestic Product (GDP) in 2012-2016 that is issued by BAPPENAS [16] and [17].

The research object is DIY Province through data of Real GRDP of 2010 Based on Business Field of 20122016. After then, the data is analyzed using quantitative descriptive analysis that can describe level of sector potential and be useful for economic development in DIY Province.

To find out the roles/contribution of forestry sector in DIY Province including regional excellent sector or not to use data analysis method can use Location Quotient (LQ) and LQ Modification methods which is the equation of LQ Revision and Symmetric LQ. In this technique, the economic activity of a region is divided into two groups. First, industrial activity that is able to serve the market in its own region or outside the region. Second, non-base industry is economic activity that only serves market in its own region. [18]

The base of the technique is economic base theory. In economic base theory, base industry produces goods and or services to meet the needs in the region or outside. [18]

The analysis equipment in this reseach are Location Quotient (LQ), Revised LQ (RLQ) and Symmetric LQ (SLQ).

\subsection{Location Quotient (LQ)}

Location Quotient (LQ) analysis states that the main function of LQ analysis is to find out which sector is excellent sector (commodity) in a region, and which sector is not excellent sector (have negative development or deficit) by comparing a region to another region with higher in certain period of time.

Furthermore, LQ formula according to [19] is written below:

$$
L Q=\frac{X i / x j}{Y i / Y}
$$

Information:

LQ = Location Quotient Index

$\mathrm{Xij}=$ GRDP value of sector $\mathrm{i}$ in Regency or City $\mathrm{J}$

$\mathrm{Xj}=$ Total GRDP value in Regency or City $\mathrm{J}$

$\mathrm{Yi}=$ GRDP value of sector $\mathrm{i}$ in Province or other reference area, for example, development area or residency area

$\mathrm{Y}=$ Total of GRDP value of employee in Province or other reference area, for example development area or residency area

Where, justification for location quotient of GRDP according to [19] is:

- If $\mathrm{LQ}>1$, then a sector said to be base sector or sector role $\mathrm{i}$ in that regency is more prominent than the sector role in the economy of DIY Province, and it may indicate that the region has surplus sector $\mathrm{i}$ product, so it can be exported to other area efficiently, and it indicates that the area has comparative excellence for sector i.
- If $L Q=1$, then a sector is said approaching base vector. Some writers categorize sectors of which LQ $=1$ is base sector. It means that sector role $\mathrm{i}$ in economy in that regency is the same as sector role in DIY Province. Therefore, if sector $i$ is developed, the result will remain the same to the economy in the area before it is developed or static.

- If $\mathrm{LQ}<1$, the it is not base vector, meaning that sector role $\mathrm{I}$ in the economy in that regency is smaller or not prominent than sector role $i$ in DIY Province. Therefore, if that sector is not as base sector and unable to be exported to other regions in economic development, sector is only able to serve local economy (non-base).

\subsection{Revised LQ (RLQ) and Symmetric LQ (SLQ)}

Estimation method used in this research is LQ modification in the form of the equation of Revised LQ (RLQ) and Symmetric LQ (SLQ). The formulation of Symmetric LQ according to [20], [18] is as follow:

$$
S L Q=\frac{R L Q-1}{R L Q+1}
$$

Information:

SLQ $=$ Symmetric Location Quotient

RLQ $=$ Revised Location Quotient

Justification for SLQ value is:

SLQ index value will be various from -1 to +1 .

SLQ $>0$, then the sector is excellent sector in that region SLQ $<0$, then the sector is not excellent sector in that region

The use of Revised LQ (RLQ) is as carried out by [20]. The result shows that LQ index and RLQ have different value. If LQ is more than one, RLQ value will be stronger. Meanwhile if LQ is smaller, then RLQ value is smaller than LQ.

Formulation of Revised LQ according to [18], [20] is as follow:

$$
R L Q=\frac{X r /(R V r-X r)}{(X n-X r) /(R V n-(X n-X r)-R V r)}
$$

Information:

RLQ $=$ Revised LQ or LQ Index of comparison result between products in independent region (from 0 to infinity as LQ index)

$\mathrm{Xr}=$ production value of sub-sector of regency

$\mathrm{RVr}=$ production total (GRDP) of regency

$\mathrm{Xn} \quad=$ production value of sub-sector of province

$\mathrm{RVn}=$ production total (GRDP) of province

Justification for RLQ value is:

$0<\mathrm{RLQ}<1$, the sector is not excellent sector

$1<\mathrm{RLQ}<\infty$, the sector is excellent sector 


\section{RESULT AND DISCUSSION}

\subsection{Forest Resource Potential in DIY Province}

According to the forest use, forest area in DIY Province is 16.819 .2 hectare or $18.94 \%$ of the total area, with detail is: conservation forest is 910.34 hectare, protected forest is 2.057 .90 hectare, and production forest is 13.851.28 hectare (Ministry of Environment and Forestry, 2017). Meanwhile, the referral for the agenda of Forestry Sector Revitalization is in line with vision and mission of forestry development in the future as commanded by the Indonesian Law No. 41 of 1999 that guarantees the existence of forest with adequate area and proportional

distribution, at least $30 \%$ (thirty percent) of watershed and or island.

The potential for such production forest can support the economic development in all aspects. Type of forest products are wood, sap, seeds, and food. Forests in DIY Province also have status of protected forest and conservation forest.

\subsection{Location Quotient (LQ), RLQ and SLQ Analysis}

The result of calculation of LQ, RLQ, and SLQ of DIY Province for forest sub-sector for the last 5 years (2012-2016) is shown on Table 2 and Table 3 to see whether forestry sub-sector is included in base -sector or non-base sector. The interesting thing found is SLQ value of forestry sub-sector and fishery sub-sector shows negative values. It can indicate that the sub-sector is possibly not excellent sector to develop in DIY Province.

Table 2. Comparison of LQ, RLQ, and SLQ Values of Forestry Sub-sector and Agriculture, Forestry, and Fishery Sectors

\begin{tabular}{|c|c|c|c|c|c|c|}
\hline \multirow{2}{*}{ YEAR } & \multicolumn{3}{|c|}{$\begin{array}{c}\text { FACTORY SUB- } \\
\text { SECTOR }\end{array}$} & \multicolumn{3}{c|}{$\begin{array}{c}\text { AGRICULTURE, } \\
\text { FORESTRY, AND } \\
\text { FISHERY SECTORS }\end{array}$} \\
\cline { 2 - 7 } & LQ & RLQ & SLQ & LQ & RLQ & SLQ \\
\hline 2012 & 1,20 & 1,20 & 0,09 & 0,68 & 0,65 & $-0,21$ \\
\hline 2013 & 1,20 & 1,20 & 0,09 & 0,67 & 0,64 & $-0,22$ \\
\hline 2014 & 1,23 & 1,24 & 0,11 & 0,62 & 0,59 & $-0,26$ \\
\hline 2015 & 1,24 & 1,25 & 0,11 & 0,61 & 0,58 & $-0,27$ \\
\hline 2016 & 1,27 & 1,28 & 0,12 & 0,60 & 0,57 & $-0,28$ \\
\hline Average & $\mathbf{1 , 2 3}$ & $\mathbf{1 , 2 3}$ & $\mathbf{0 , 1 0}$ & $\mathbf{0 , 6 4}$ & $\mathbf{0 , 6 0}$ & $-\mathbf{0 , 2 5}$ \\
\hline
\end{tabular}

Source: National Development Planning Agency (BAPPENAS) and Central Bureau of Statistics of DIY Province in 2012-2016 (processed data)

Based on the calculation using LQ and RLQ method for 5 (five) Regencies and 1 City of Yogyakarta in 2012-2016 can be interpreted that forestry sub-sector can be excellent for regional economic development if shorted based on the prospect and potential, that is, Gunungkidul, Kulonprogo, Bantul and Sleman. Gunungkidul, and it is shown on the average value of LQ $>1$ (4.08) and the average RLQ (8.06). It is followed by Kulonprogo which is shown on the average value of LQ $>1$ (3.69) and the average RLQ (3.78). However, based on the calculation of SLQ, not all base sectors in Bantul and Sleman become excellent sectors, which is shown on negative SLQ value $(S L Q<0)$ with the average value of SLQ in Bantul Regency is -0.34 and in Sleman is -0.72 . Moreover, the average value of LQ and RLQ in Yogyakarta City is zero ( 0 ) and its average SLQ is -1 , so the forestry sub-sector in Yogyakarta City is not excellent sector in that region.

Index result of LQ, RLQ, and SLQ shows that forestry sub-sector has good economic strength to increase the economic development in DIY Province, and the sub-sector is able to meet the needs in its own area, even it has potential to export.

In the calculation of GDP and GRDP is applied in Indonesia until now, which is counted in GDP /GRDP of forestry sub-sector, which is a part of agriculture sector, is only upstream activity and the primary industry of processing forest products.

Meanwhile, activities in downstream sector and advanced forest product industry are not included in added value that is calculated in forestry sub-sector. Furthermore, due to the absence of market transaction, the calculation of GDP/GRDP does not include environmental service given by forests such as the ability to retain water, flood, and erosion; as a place for biodiversity living and even carbon sinks, all of which there is no market transaction in the use of such environmental service products.

These environmental services have not been included because those are considered as public goods and have externality, in which those who utilize the environmental services do not have to pay for them to the forest management. What it means by public goods is characterized by the exclusion of "exclusion principle" and "rivalry in consumption".

Table 3. Comparison of LQ, RLQ, SLQ values from 2012 to $2016(\%)$

\begin{tabular}{|l|l|l|l|}
\hline \multicolumn{1}{|c|}{ Regency/City } & \multicolumn{3}{|c|}{ Average in 2012 - 2016 } \\
\hline & LQ & RLQ & SLQ \\
\hline Yogyakarta City & $\mathbf{0 , 0 0}$ & $\mathbf{0 , 0 0}$ & $\mathbf{- 1 , 0 0}$ \\
\hline Sleman Regency & $\mathbf{0 , 2 2}$ & $\mathbf{0 , 1 6}$ & $\mathbf{- 0 , 7 2}$ \\
\hline Bantul Regency & $\mathbf{0 , 5 4}$ & $\mathbf{0 , 4 9}$ & $\mathbf{- 0 , 3 4}$ \\
\hline Kulonprogo Regency & $\mathbf{3 , 6 9}$ & $\mathbf{3 , 7 8}$ & $\mathbf{0 , 5 8}$ \\
\hline Gunungkidul Regency & $\mathbf{4 , 0 8}$ & $\mathbf{8 , 0 6}$ & $\mathbf{0 , 7 8}$ \\
\hline
\end{tabular}

Source: Central Bureau of Statistics of DIY Province in 20122016 (processed data) 


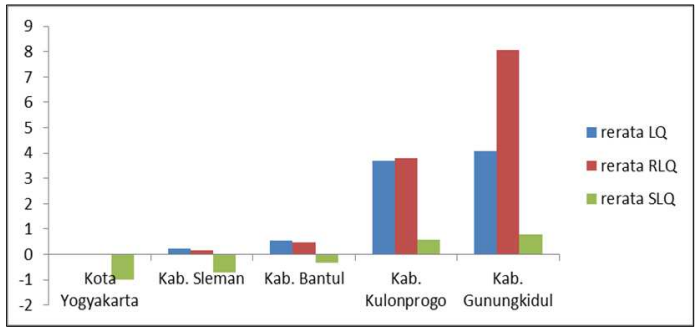

Fig 1. Comparison of the average value of LQ, RLQ and SLQ of the DIY Province for the period of 2012-2016

\section{CONCLUSION}

Based on the research result, it can be concluded that forestry sub-sector in DIY Province is one of the excellent sub-sectors in the economy of DIY Province, especially in Kulonprogo and Gunungkidul regencies for the period of 2012-2016. It is shown that during the period of 2012-2016, forestry subsector products have been able to meet the local and provincial needs in DIY Province, as well as have potential to export.

\section{References}

[1] Bayu. D.J. 2017 "Perpres soal Perencanaan Pembangunan Rendah Karbon Akan Diterbitkan". https://katadata.co.id, accessed on 25 June 2018.

[2] Budianta, A. (2010) "Revitalisasi Pertanian Penggerak Utama Pembangunan Kawasan Perdesaan di Indonesia," MEKTEK Tahun XII, vol. No. 1, no. Januari 2010. 69, pp. 69-76.

[3] Wicaksono, I.A. (2011) "Analisis Location Quotient Sektor dan Subsektor Pertanian pada Kecamatan di Kabupaten Purworejo," MEDIAGRO, vol. 7, no. 2. 12, pp. 11-18.

[4] Badan Litbang Pertanian. (2005) "Revitalisasi Pertanian, Perikanan dan Kehutanan,” II.1, pp. II.1-II.17.

[5] UNEP dan UNORCID. (2005) "Studi Penilaian Ekosistem Hutan". 1, pp. 1-4.

[6] Warsito, P.W., Sumardi, S. A. Awang. (2003) "Meningkatkan Peranan Sumber Daya Hutan dalam Pembangunan Nasional," in Seminar oleh Alumni dalam rangka Dies Natalis dan Reuni Akbar 2003 Panca Windu Fakultas Kehutanan UGM, no. 19 September 2003. 1, pp. 1-5.

[7] Prasetyo, W. A. (2017) "Kontribusi Sektor Kehutanan terhadap Pendapatan Asli Daerah (PAD) di Kabupaten Kuantan Singingi".Jom Faperta Vol. 4 No. 1 Februari 2017. 2, pp. 1-9.

[8] Badan Litbang Kehutanan. (2010) "Peranan dan Dampak Sektor Kehutanan pada Perekonomian Indonesia". Bogor : Badan Penelitian dan Pengembangan Kehutanan. 1, pp. 1-4.
[9] Setyarko, Y. (2008) "Kontribusi Hijau Sektor Kehutanan pada PDRB dan Pembangunan Regional Kabupaten Batang hari Provinsi Jambi," J. Ekon. Lingkung., vol. 12, no. 2. 5, pp. $1-20$.

[10] Husna, N., I. Noor and M. Rozikin. (2012 ) "Analisis Pengembangan Potensi Ekonomi Lokal untuk Menguatkan Daya Saing Daerah di Kabupaten Gresik," J. Adm. Publik (JAP), vol. 1, no. 1. 191, pp. 188-196.

[11] Badan Pusat Statistik Kota Yogyakarta. (2017) "Produk Domestik Regional Bruto Provinsi Daerah Istimewa Yogyakarta Menurut Lapangan Usaha 2012-2016". Yogyakarta: BPS Kota Yogyakarta. 77, pp. 1-97

[12] Badan Pusat Statistik Kabupaten Sleman. (2017) Produk Domestik Regional Bruto Menurut Lapangan Usaha Kabupaten Sleman 2012-2016. Sleman: Badan Pusat Statistik Kabupaten Sleman. 71, pp. 1-92.

[13] Badan Pusat Statistik Kabupaten Kulon Progo. (2017) "Produk Domestik Regional Bruto Kabupaten Kulon Progo Menurut Lapangan Usaha 2012-2016". Kulon Progo: Badan Pusat Statistik Kabupaten Kulon Progo. 135, pp. 1163

[14] Badan Pusat Statistik Kabupaten Gunungkidul. (2017) "Produk Domestik Regional Bruto Kabupaten Gunungkidul Menurut Lapangan Usaha 2012-2016". Wonosari: Badan Pusat Statistik Kabupaten Gunung Kidul. 111, pp.1133.

[15] Badan Pusat Statistik Kabupaten Bantul. (2017) "Produk Domestik Regional Bruto Kabupaten bantul Menurut Lapangan Usaha 2012-2016". Bantul: Badan Pusat Statistik Kabupaten Bantul. 90, pp.1-114.

[16] Badan Pusat Statistik. "PDB Triwulanan Atas Dasar Harga Konstan 2010 Menurut Lapangan Usaha Tahun 2014-2018". www.bps.go.id, accessed on 25 June 2018

[17] Badan Pusat Statistik, "PDB Triwulanan Atas Dasar Harga Konstan 2010 Menurut Lapangan Usaha Tahun 2010-2013." www.bps.go.id, accessed on 25 June 2018.

[18] Kurnianto, D. (2010) "Analisis Sektor Unggulan Daerah dengan Modifikasi Location Quotient: Studi Kasus di Kabupaten Ngawi," .Thesis: Fakultas Ekonomika \& Bisnis, Universitas Gadjah Mada. 9, 12 dan 18, pp. 196

[19] Nugroho, SBM. (2004) "Model Ekonomi Basis Untuk Perencanaan Pembangunan Daerah". Dinamika Pembangunan, vol. 1, no. Juli 2004. 25, pp. 23-30.

[20] Chiang, S. (2008) "Location Quotient and Trade,” Ann. Reg. Sci., vol. 43. 403, pp. 399414 